ОСОБЛИВОСТІ РОЗВИТКУ

СВІТОВОГО ГОСПОДАРСТВА ТА МЕВ

УДК 330.131.7/342

\title{
RISK APPETITE STATEMENT AS MULTINATIONAL ENTERPRISES' INNOVATIVE RISK MANAGEMENT TOOL
}

\section{ДЕКЛАРАЦІЯ РИЗИК-АПЕТИТУ ЯК ІННОВАЦЙНИЙ ІНСТРУМЕНТ РИЗИК-МЕНЕДЖМЕНТУ БАГАТОНАЦІОНАЛЬНИХ ПІДПРИЕМСТВ}

\section{ДЕКЛАРАЦИЯ РИСК-АППЕТИТА КАК ИННОВАЦИОННЫЙ ИНСТРУМЕНТ РИСК-МЕНЕДЖМЕНТА МНОГОНАЦИОНАЛЬНЫХ ПРЕДПРИЯТИЙ}

\section{Rasshyvalov D.}

PhD (Economics), Head of the Chair of the Department of International Business of the Institute of International Relations of Taras Shevchenko National University of Kyiv. Email: rasshyvalovd@ukr.net

\section{Rushkovskyi M.}

PhD Student, Department of International Business of the Institute of International Relations of Taras Shevchenko National University of Kyiv. E-mail: rushkovskyi@gmail.com

\section{Расшивалов Д. П.}

Кандидат економічних наук, Завідувач кафедри міжнародного бізнесу Інституту міжнародних відносин Київського національного університету імені Тараса Шевченка. E-mail: rasshyvalovd@ukr.net

\section{Рушковський М. В.}

Аспірант, кафедра міжнародного бізнесу Інституту міжнародних відносин Київського національного університету імені Тараса Шевченка. E-mail: rushkovskyi@gmail.com

\section{Расшивалов Д. П.}

Кандидат экономических наук, Заведующий кафедры международного бизнеса Института международных отношений Киевского национального университета имени Тараса Шевченко. E-mail: rasshyvalovd@ukr.net

\section{Рушковский М. В.}

Аспирант, кафедра международного бизнеса Института международных отношений Киевского национального университета имени Тараса Шевченко. E-mail: rushkovskyi@gmail.com

Abstract. This article analyzes the preconditions and genesis of the concept of risk appetite from the first works on rational decision problem in the conditions of risk and uncertainty, researched by John von Neumann and Oscar Morgenstern in the mid of 20th century within the description of the utility function, to the modern use of Risk Appetite Statement as an innovative risk management tool of the multinational enterprises (MNE). A special focus is placed on the practical use and benefits of the Risk Appetite Statement within the process of internationalization and MNE development of the both financial and non-financial sectors of economy of the US, European Union and Ukraine. The paper argues that the Risk Appetite Statement tool not only sets limits on risks, but also provides other important advantages for MNE in forming a business development strategy 
and implementing key projects. Practical application of the Risk Appetite Statement in the largest state-owned enterprise of Ukraine NJSC "Naftogaz of Ukraine" is considered in detail.

Key words: risk appetite, risk appetite statement, risk management, multinational enterprises, strategy.

Анотація. Стаття аналізує передумови виникнення та генезу концепиії ризик-апетиту від перших робіт з вирімення задач раціонального вибору в умовах ризику та невизначеності, які були досліджені Джоном фон Нейманном та Оскаром Моргенштерном y середині XX століття в рамках описання функиії корисності, до сучасного використання Декларації ризик-апетиту як інноваційного інструменту ризик-менеджменту багатоначіональних підприємств (БНП). Окрема увага приділяється практичному застосуванню та перевагам Декларації ризик-апетиту в рамках прочесів інтернаціоналізачіі та розвитку БНП як фінансового, так $і$ нефінансового секторів економіки США, Свропейського Союзу та України. В статті аргументовано, щуо інструмент Деклараџії ризик-апетиту не лише встановлює обмеження на ризики, але також забезпечує інші важливі переваги для БНП при розробиі стратегії розвитку бізнесу та реалізачії ключових проектів. Детально розглянуто практичне застосування Декларачії ризик-апетиту в найбільшій державній компанії України НАК «Нафтогаз України».

Ключові слова: ризик-апетит, декларація ризик-апетиту, ризик-менеджмент, багатонаціональні підпиємства, стратегія.

Аннотация. Статья анализирует предпосылки возникновения и генезис конщепџии риск-аппетита от первых работ по решению задач рационального выбора в условиях риска u неопределенности, которые были исследованы Джсоном фон Нейманном и Оскаром Моргенштерном в середине XX века в рамках описания функиии полезности, до современного использования Деклараџии риск-аппетита как инновационного инструмента риск-менеджмента многоначиональных предприятий (МНП). Особое внимание уделяется практическому применению и преимуществам Декларащии риск-аппетита в рамках процессов интерначионализации и развития МНП как финансового, так и нефинансового секторов экономики США, Европейского Союза и Украиньл. В статье аргументировано, что инструмент Декларации риск-аппетита не только устанавливает ограничения на риски, но также обеспечивает другие важные преимущества для МНП при разработке стратегии развития бизнеса и реализации ключевых проектов. Детально рассмотрено практическое применение Декларации риск-аппетита в крупнейшей государственной компании Украинь НАК «Нафтогаз Украинь»».

Ключевые слова: риск-аппетит, декларация риск-аппетита, риск-менеджмент, многонациональные предприятия, стратегия.

\section{Introduction}

Rapid internationalization and development of multinational enterprises (MNE) over the past two decades, and the global financial crisis of 2008-2009, have highlighted the relevance and urgency of developing effective tools for identifying and assessing the risks and threats faced by MNE in the pursuit of their strategic goals, providing necessary resources to reduce them. Successful MNE are paying more and more attention to the development of internal risk management systems that enhance strategic planning, help to achieve goals, and increase responsiveness to emerging challenges. The concept of risk appetite definition has become an innovative tool for the development of such systems in the last decade. In addition to meeting the requirements of corporate governance standards, stakeholders at all levels (shareholders, analysts, investors, the public) formulate a demand for MNE in both financial and non-financial sectors to clearly define their readiness to risk in order to achieve strategic goals, i.e formulate their risk 
appetite. Today, more and more MNE of the US, European Union and Ukraine are developing and implementing Risk Appetite Statement in order to be able to respond to existing and future challenges in a timely and effective manner.

\section{Theoretical approaches review}

The first scientific research in the field of risk compensation, which is embedded in the concept of risk appetite, can be traced in the utility function formulated by John Von Neumann and Oskar Morgenstern in 1947 [Neumann, Morgenstern, 1947]. The utility function describes decision making in terms of risk and uncertainty. An individual who takes a decision in terms of uncertainty (lottery) determines which level of income will increase its utility. Based on this assumption, the utility function $u(X)$ can describe three approaches to risk - risk-seeking, risk-neutral and riskaverse, as shown in Figure 1 below.

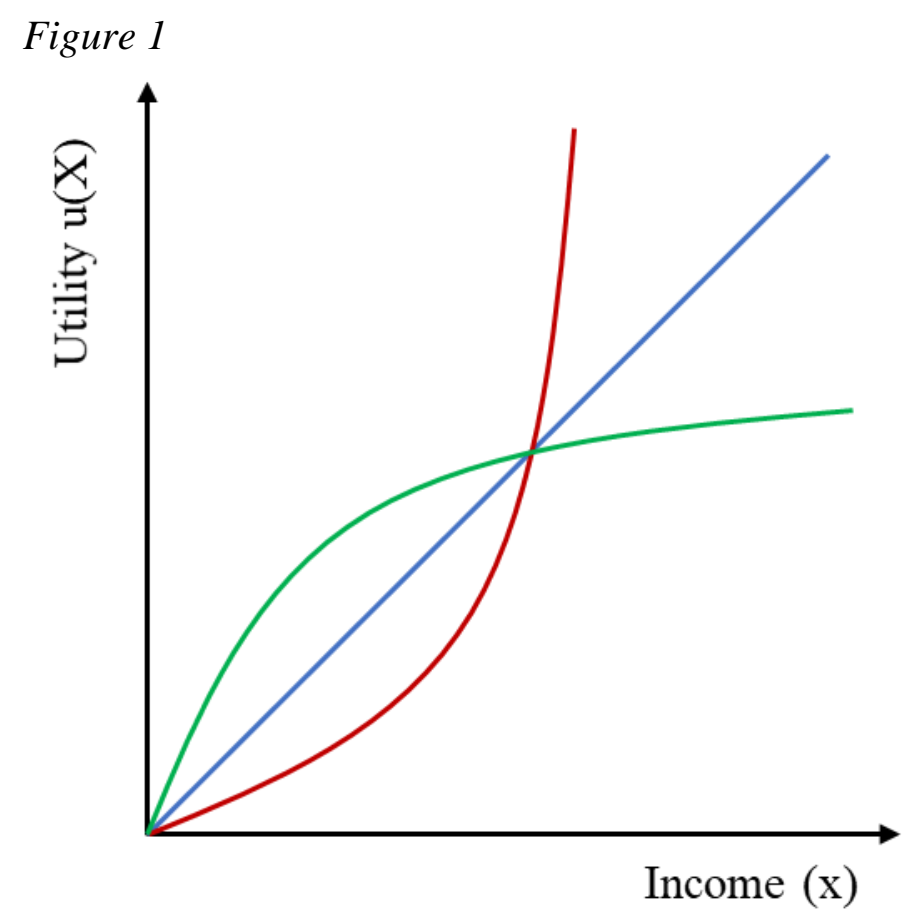

Risk-seeking condition (high risk appetite) is marked on the chart in red and indicates that additional utility unit is provided by less income than at risk-neutral approach (blue straight line) and risk-aversion, i.e. low risk appetite (marked in green).

Another important step in the development of scientific knowledge that describes individual's behavior under uncertainty is Prospect Theory, which was formulated by Daniel Kahneman and Amos Tversky in 1979 in the article "Prospect Theory: An Analysis of Decision under Risk" [Kahneman, Tversky, 1979]. According to Prospect Theory, individuals tend to overweight low probability and underweight high probability. This trend, called the certainty effect, contributes to the risk-averse in the choice that assumes certain benefits, and the risk-seeking that involves certain loss, which is accordingly reflected in Figure 2. 
Figure 2

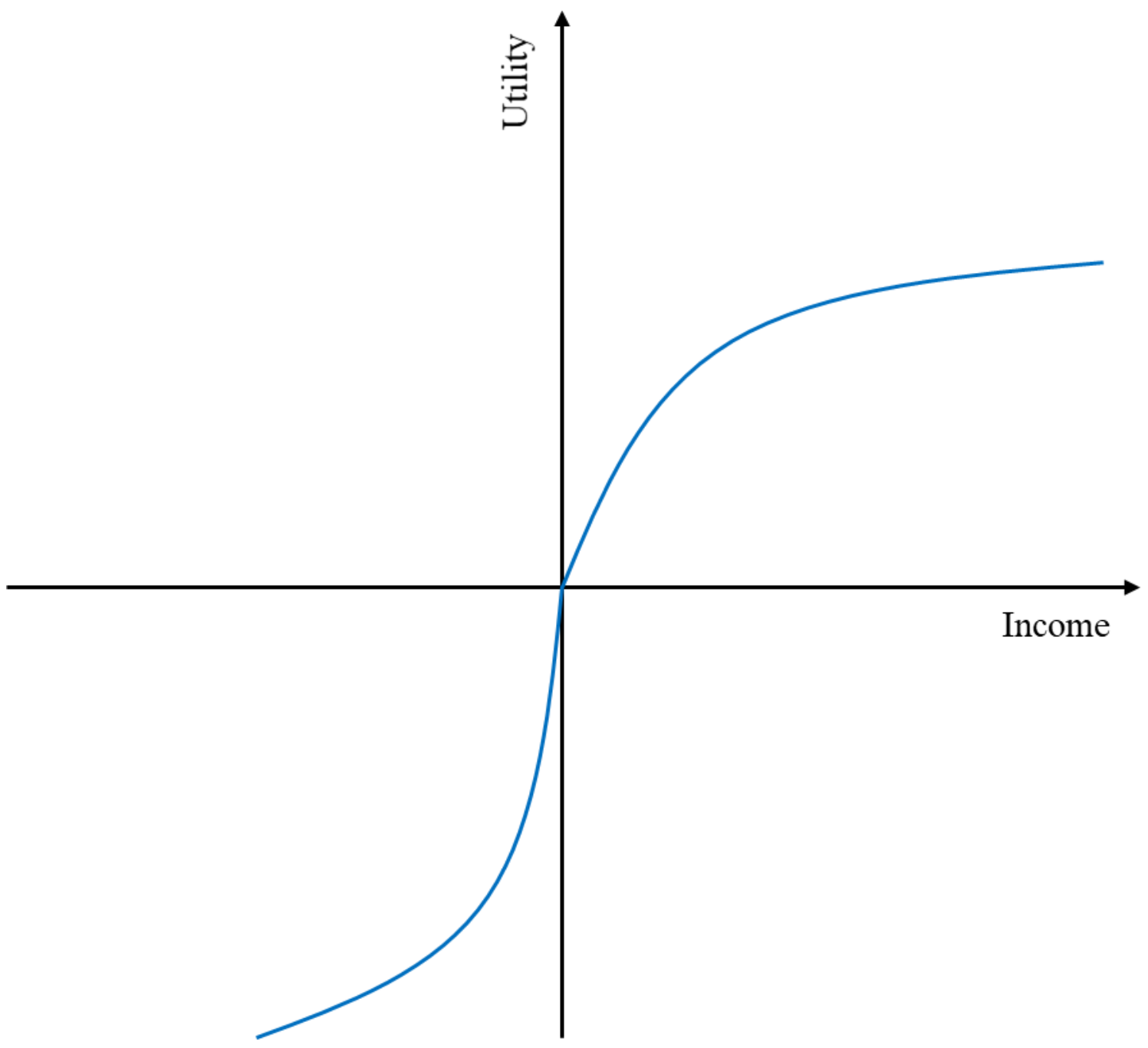

Risk-seeking condition in Prospect Theory partially describes the moderate or high risk appetite of an individual in the certainty conditions.

The modern concept of risk appetite was formulated in 2004 by the British Treasury in the book "The Orange Book Management of Risk - Principles and Concepts" [HM Treasury, 2004], as the amount of risk that an organisation is prepared to accept. Further development of the risk appetite tool appeared in document "Enterprise Risk Management - Integrated Framework" [Committee of Sponsoring Organizations of the Treadway Commission, 2004], issued by the Committee of Sponsoring Organizations (COSO) in 2004, and identified risk appetite as an important MNE management tool for evaluating strategic alternatives and projects, setting related objectives, and developing mechanisms to manage related risks.

During the global financial crisis of 2008-2009, many companies around the world faced unknown or underestimated risks. In addition, financial losses and negative economic impact were multiplied by systemic risks associated with financial counterparties, business partners, as well as macroeconomic and interstate relations. In response, governments and regulators have introduced much higher regulatory standards and capital requirements. The focus was on the financial sector, which appeared to be the most vulnerable to global financial turmoil. In particular, the Basel Committee on Banking Supervision developed a regulatory framework Basel III [Basel Committee on Banking Supervision, 2010], which regulates requirements for bank capital adequacy, stress testing mechanisms and management of liquidity risk and sets binding definition of risk appetite [Basel Committee on Banking Supervision, 2009]. Basel III regulatory framework was introduced alternately in the US and the European Union. 


\section{Current stage of risk appetite concept development}

Today, leading MNE, when forming a business development strategy and implementing key projects, make decisions about the trade-offs and deviations they may encounter during implementation. That is why it is extremely important for the successful implementation of the developed strategy to have it mutually integrated with MNE's risk appetite, which is comprehensively reflected in the Risk Appetite Statement.

Risk Appetite Statement determines the level and amount of risk that MNE can afford to incur based on their financial and operational capabilities, and thus be able to achieve their goals. This is necessary to protect MNE against potential damage with the threat level, under certain circumstances, that could be fatal for the company, or cause large losses. Figure 3 below shows an example of a combination of a MNE's strategy, potential risks and opportunities, and risk appetite over time.

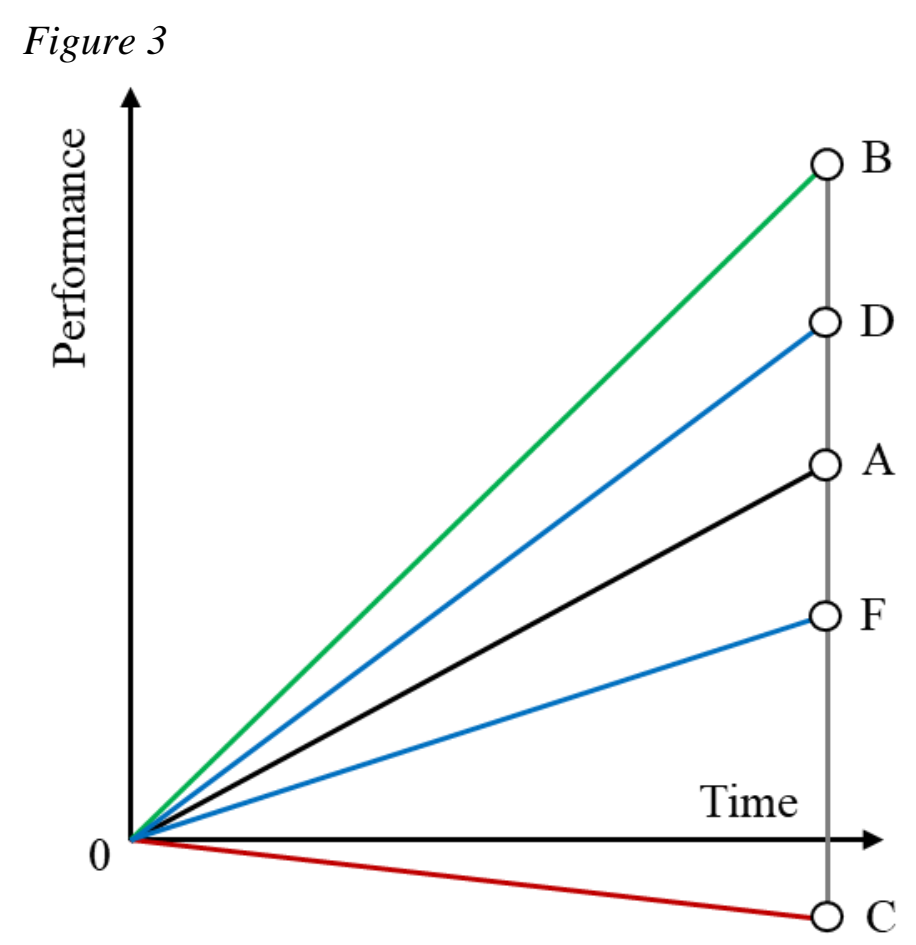

On Figure 3:

- $\quad$ segment $0 \mathrm{~A}$ reflects the strategic goals set by MNE;

- zone B0A reflects potential positive opportunities that may arise;

- zone $\mathrm{A0C}$ reflects potential risks and negative consequences that may arise;

- zone B0C reflects uncertainty and potential changes in the operational environment of MNE;

- zone D0F reflects MNE's risk appetite.

MNE's management must clearly define how the strategy will work in line with risk appetite, how it will encourage the organization to set goals and ultimately allocate resources effectively.

Although the main purpose of the Risk Appetite Statement is to establish limits on risk, it also provides other important benefits, including [Institute of Management Accountants, 2015]:

- developing a common understanding and language for discussing risk at management and business levels;

- promoting risk awareness and enforcing the desired risk culture throughout MNE; 
- aligning business strategy with risk management to provide a balance between financial performance and risk control requirements;

- quantifying, monitoring and reporting risks to ensure that they are within acceptable and manageable levels;

- embedding risk-oriented approach into strategic and operational decisions;

- integrating risk appetite with other risk management tools, including key performance indicators (KPIs) and key risk indicators (KRIs), economic capital and stress-testing;

- meeting the needs of external stakeholders (e.g., regulators, investors, rating agencies and business partners) for risk management system transparency, financial, economic and social sustainability.

\section{Current practice of Risk Appetite Statement utilization at MNE and in Ukraine}

At the present stage more and more MNE of the US and the European Union are developing and implementing the Risk Appetite Statements to protect themselves against systemic risks associated with counterparties, partners, macroeconomic and international links in the framework of implementation of their strategy and key projects. According to a survey of the National Association of Corporate Directors (NACD) conducted by the international company PwC, in 20132014 26\% [National Association of Corporate Directors, 2013-2014] of the companies had comprehensive Risk Appetite Statements. In 2015 this figure reached 35\% [National Association of Corporate Directors, 2015]. Among these companies leading MNE of financial and non-financial sectors, for example, French financial conglomerate Société Générale [Société Générale, 2019], transnational oil \& gas company BP [BP, 2018], Nordic and Baltic countries development bank Nordic Investment Bank [Nordic Investment Bank, 2019].

Best practices of corporate governance, including risk management, are being actively implemented in the operations of large companies in Ukraine. In 2015, corporate governance reform developed in line with the OECD principles started for state-owned enterprises. In particular, one of the main tasks of the newly formed in 2016 Supervisory Board of the largest stateowned company of Ukraine NJSC "Naftogaz of Ukraine", was to establish a comprehensive risk management function [Naftogaz of Ukraine, 2016]. One of the steps in the formation of the vertically integrated risk management system at Naftogaz Group in 2018 was the development of Risk Appetite Statement, which was approved by the Supervisory Board [Naftogaz of Ukraine, 2018]. This document defines risk appetite of Naftogaz Group in its main areas of operations: production, transit and distribution of natural gas, implementation of the PSO regulations, corporate governance and reform and unbundling, liquidity and currency risk management, meeting the requirements of existing and new licenses for production and distribution of natural gas, etc.

\section{Conclusions}

The general concept of risk appetite emerged in the 20th century and began to develop actively in the last two decades within the framework of development of risk management system as an integral component of operations of successful MNE. Risk Appetite Statement is an innovative risk management tool that allows to diagnose risk level across all operations of MNE, identify the most problematic areas, and map actions that will reduce the risk of activity where it exceeds the permitted levels, or maintain acceptable risk levels in those areas, where it is today. On the other hand, Risk Appetite Statement is used as a single platform for discussing risks at the management level, as well as in dialogue with the external stakeholders (regulators, investors, rating agencies and business partners).

Today, more and more attention is being paid to the Risk Appetite Statement tool at both MNE and government levels around the world, including Ukraine. 


\section{References}

1. Neumann J., Morgenstern O. (1947) 'Theory of games and economic behavior, 2nd edition', Princeton: Princeton University Press.

2. Kahneman D., Tversky A. (1979) 'Prospect Theory: An Analysis of Decision under Risk', Econometrica - March 1979 - Vol. 47 - No. 2, pp. 263-292.

3. HM Treasury (2004) 'The Orange Book Management of Risk - Principles and Concepts', Crown copyright, <https://www.who.int/management/general/risk/managementofrisk.pdf>

4. Committee of Sponsoring Organizations of the Treadway Commission (2004) 'Enterprise Risk Management - Integrated Framework'.

5. Basel Committee on Banking Supervision (2010) 'Basel III: international regulatory framework for banks' <https://www.bis.org/bcbs/basel3.htm?m=3\%7C14\%7C572>

6. Basel Committee on Banking Supervision (2009) 'Enhancements to the Basel II framework'< https://www.bis.org/publ/bcbs157.pdf>

7. Institute of Management Accountants (2015) 'Implementing an Effective Risk Appetite' < https://www.imanet.org/-/media/8150b134bafd42aaaf5267bf49d6d2a3.ashx>

8. National Association of Corporate Directors (2013-2014) 'Public Company Governance Survey'.

9. National Association of Corporate Directors (2015) 'Public Company Governance Survey'.

10. Société Générale 'Integrated Report 2018-2019' $<$ https://www.societegenerale.com/sites/default/files/documents/Rapportintegre/2019/ri_sg_2019_eng.pdf>

11. BP 'BP Annual Report and Form 20-F 2018' $<$ https://www.bp.com/content/dam/bp/business-sites/en/global/corporate/pdfs/investors/bp-annualreport-and-form-20f-2018.pdf>

12. Nordic Investment Bank (2019) 'Risk Appetite Statement' $<$ https://www.nib.int/filebank/a/1559825579/0da81db1c3a0db6015ec2f4e69054275/9592-

NIB_Risk_Appetite_Statement_June_2019.pdf>

13. NJSC "Naftogaz of Ukraine" (2016) 'Naftogaz supervisory board was fully formed' <http://www.naftogaz.com/www/3/nakweben.nsf/0/E495C1CDCD218F2EC2257F9D003F2592?O penDocument\&Highlight $=0$, corporate $\% 20$ governance>

14. NJSC "Naftogaz of Ukraine" (2019) 'Annual Report 2018' pp.108-109 <http://www.naftogaz.com/files/Zvity/Annual-Report-2018-engl.pdf> 